\title{
Journalism and the political structure
}

\author{
The local media system in Norway
}

\author{
Helle Sjøvaag, Truls André Pedersen ${ }^{\mathrm{II}}$ \& Ole Martin Lægreid ${ }^{\mathrm{III}}$ \\ I Department of Media and Social Sciences, University of Stavanger, Norway \\ II Department of Information Science and Media Studies, University of Bergen, Norway

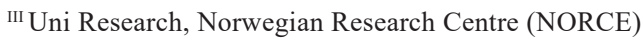

\begin{abstract}
This article assumes a media system perspective on the local news media structure in Norway, using a dataset of 847,487 news articles collected from 156 Norwegian news outlets in 2015-2017. Using a series of hypotheses, the analysis uses Latent Dirichlet Allocation (LDA) topic modelling to ascertain to what extent local journalism meets community information needs through infrastructure, output and performance. The analysis finds that the size of the publisher and the size of the community covered matter more for hard news coverage than regulatory factors. To that end, the results indicate that the Norwegian local media system is somehow shaped by the geography of the political landscape. The results and their contributions are discussed in light of media systems theory and local journalism structures.
\end{abstract}

Keywords: local news media, media systems, political journalism, LDA, statistical analysis

\section{Introduction}

Media and political structures are intimately connected. In fact, media systems theory suggests that media models are rooted in the political and economic fabric of a society. Journalism, as such, is in a 'close relationship to the political world' (Hallin \& Mancini, 2004: 13). While media systems theory assumes that this is the case at the level of the nation state, few attempts have been made to analyse this system connection within the nation state - such as the relationship between the local political decision-making level and local news media (for notable exceptions, see Powers et al., 2015; Wadbring \& Bergström, 2017). Filling this gap is crucial, however, in substantiating media systems theories beyond the level of national news media and their relationship to parliamentary and government structures. Democratic corporatist media systems, and in particular the 'Nordic media welfare states' (Syvertsen et al., 2014), are largely characterised by a dispersed local newspaper structure. Investigating the relationship between news media and political structures at the local level can thus give added insight into the particulari-

Sjøvaag, H., Pedersen, T. A. \& Lægreid, O. M. (2019). Journalism and the political structure: The local media system in Norway in Nordicom Review, 40(2): 63-89. doi:10.2478/nor-2019-0034. 
ties of the Scandinavian media systems. To that end, the present article asks: How is the political municipality structure reflected in the Norwegian local media structure, and to what extent are the particularities of the press structure associated with local media's role in performing local political oversight?

We approach this question as a series of hypotheses, asking to what extent the characteristics of local journalism and municipality structures reflect political news reporting. The aim is to establish how the local features of the Norwegian media system - operationalised as monopolistic local markets, independent ownership and press support - enable journalistic monitoring of local political processes. We, in turn, analyse how central features of local political structures - in particular their location, labour markets (operationalised as unemployment rates) and political stability (votes for incumbent), impact on political news reporting. These features reflect core aspects of market structure and reach embedded in Hallin and Mancini's (2004) media systems model, mobilised here to enable an analysis of the level of localism and journalistic professionalism in the Norwegian local media system. The analysis is based on structural analysis as well as a mix of descriptive and predictive statistical analyses on a corpus of 847,487 digital news articles collected from 156 online newspapers in 2015-2017, using Latent Dirichlet Allocation (LDA) topic modelling. The extent to which these assumptions are supported in turn enables a discussion of how local media system features contribute to media systems theory.

In the following, we first discuss the relevant literature and present the background to the Norwegian case. Second, we describe the data and methods used to perform the analyses. Third, we present the results of the analyses, and finally, discuss the results in light of theory.

\section{Literature review}

This analysis is nested in the media systems theory framework, resting largely on local journalism's community function. When Hallin and Mancini $(2004,2012)$ emphasise press structure, corporatism and localism as key to media systems differences, they highlight in particular the role of local newspapers in embedding political power in Scandinavian societies. The extent to which local journalism meets community information needs, however, depends on its infrastructure, output and performance (Napoli et al., 2017).

\section{Media systems}

The concept of a system is based on the assumption that the parts that make up a system are involved in necessary and dependent relationships (Hardy, 2008). While the idea of systems has been criticised for being too deterministic in outlining relationships of dependency and stability (Flew \& Waisbord, 2015), with particular criticism towards the nation state as analytical variable (e.g. Livingstone, 2012), systems also contain principles that help to unlock common factors shaping developments, establish functions that produce differences, and make connections that explain similarities. Because media systems are largely state-bound concepts (Hardy, 2008), journalism operates under political, economic, professional and regulatory forces that entail 'repositories of historically shaped institutional constraints' (Benson et al., 2012: 24). As such, most 
media systems models, from Four Theories of the Press (Siebert et al., 1956) onward, are elite power models where influence flows between the government and the press (Ostini \& Ostini, 2002). Embedded in media systems perspectives are, however, the role played by different subsystems within national settings (e.g. Christians et al., 2010).

Here, local media ecosystems have been referred to as the 'microcosmos', characterised by the close proximity between journalism, its sources and the public (Guimera et al., 2018). Because local news ecosystems differ across nations - depending on their media systems and their regulation, competition and perceptions of journalistic excellence - analysing local news content is key to refining national media systems models (e.g. Leupold et al., 2018; Nielsen, 2015; Powers et al., 2015). Aside from content, the structure of the community itself, and not least its demographics, affect the pattern of news coverage (Funk \& McCombs, 2017). According to Napoli and colleagues (2017), the extent to which local journalism meets community information needs thus depends on its infrastructure (the availability of sources), output (the quantity of news) and performance (the quality of content).

In the Scandinavian countries, the press has historically been in a mediating position between citizens and the political elites (Hallin \& Mancini, 2004; Syvertsen et al., 2014). The presence of a comprehensive local newspaper structure in Norway is thus connected with the dispersed demographics in the country, which has been tied historically to centre/periphery cleavages (Rokkan, 1967) that created political and cultural sub-communities with localism characteristics. Local newspapers are instrumental in sustaining public debate and political engagement in smaller communities (Firmstone \& Coleman, 2014), as well as in reinforcing local identity and settlement patterns (Syvertsen et al., 2014). This is because, as Hess and Waller point out (2016), democracy and public spheres begin at the local level. Nielsen (2015) has therefore referred to local media as keystone media, as they provide specific and very important types of information helping people stay informed about local politics. To that end, local journalism has been found to exhibit a particularly strong watchdog ideal in different countries (Firmstone \& Coleman, 2014; Hanusch, 2015; Nord, 2007). Moreover, the political embedment of the local press in Norway instituted strong connections between readership, politics and commercial newspaper operations that have helped deter circulation decline in the local newspaper structure (Slaatta, 2015). Hence, to the extent that history is important in comprehending the shape of media systems (Hallin \& Mancini, 2012), the characteristics of local political structures are crucial factors in understanding journalism in Norway.

\section{Local news structures}

Local newspapers have been described as the 'backbone' of the Norwegian media structure (Mathisen, 2010; Syvertsen et al., 2014), acting as a social 'glue' (Engan, 2016; Espeland, 2006), and performing a community function as much as they serve an information function (Ekström et al., 2006; Oberholzer-Gee \& Waldfogel, 2009). Studies have consistently found that there is a connection between local newspapers, readership and civic engagement (Bruns \& Himmler, 2011; Lie, 2018; Skogerbø \& Winsvold, 2011). As such, local news media are linked with the general health of the democratic system, as they constitute local politicians' main arena and the primary source of local political coverage for local citizens (Skogerbø \& Krumsvik, 2015). Local newspapers 
have also been found to contribute to the diversity of the overall media landscape (e.g. Mathisen \& Molandstø, 2015; Sjøvaag \& Pedersen, 2019), not least because of the lack of substitutes for local news (Bridges et al., 2002; Gentzkow \& Shapiro, 2008). For this reason, state subsidies to newspapers (press support) are often tied to circulation, frequency of publication, and market position (Ots, 2009).

Norway has a comparatively abundant and decentralised newspaper market, with 223 titles published nationally, the majority (75\%) of which are local in distribution and profile. The median circulation of Norwegian newspapers is 4,000 (average 8,700, SD 18,300). Newspaper ownership is primarily national, with regional concentration. While 30 per cent of Norwegian newspapers have independent ownership, around 70 per cent of this occurs at the local level (Sjøvaag et al., 2019). Local markets are comparatively strong (Allern \& Pollack, 2017), with lower drops in circulation than single-sales copy papers and metropolitan newspapers. This is not least because most local newspapers operate in monopolistic markets (Lacy, 1984; Rosse, 1975). One might surmise from these systemic trends that national omnibus newspapers aiming for general audiences have lost ground while local news has, as of yet, managed to retain its position. Moreover, while local news have done poorly in liberal media systems such as the U.K., they remain comparatively strong in democratic corporatist countries (cf. Newman et al., 2019).

Readers typically value local newspapers because of the local information and public connection they offer (Costera Meijer \& Bijleveld, 2016). Local news is a source of community engagement (Gulyas et al., 2018; Lie, 2018), and thus also social capital (Hess, 2015). The local newspaper is the second most trusted news brand in Norway, after the public service broadcaster (Newman et al., 2019). In many markets local newspapers are the only source of information citizens have about their communities. Coupled with high trust, and the absence of freesheets, Norwegian local newspapers have therefore retained high reach in local markets, in many cases over 60 per cent (see for instance Amedia, 2018, 2019). However, audiences for local newspapers in Norway mainly consist of readers over the age of 67, predominantly women and people with high school education or shorter university degrees (SSB, 2018). It remains a problem, then, for many local newspapers that their readership consists largely of older age groups who prefer the print edition (e.g. Jenkins \& Nielsen, 2018; Wadbring \& Bergström, 2017).

Given these structural characteristics, this article examines to what extent local political and media structures impact on the amount of hard, political news that publishers carry in local news markets, gauging the extent to which local news enables political oversight supporting local democracy.

\section{Data and method}

The analysis is based on two sets of data. The first dataset consists of structural information about the 156 publishers included in the analysis, their markets and their distribution across local municipality structures. This includes 153 newspapers, one online-only news site (Nettavisen) and two public service broadcasters (NRK as the state-owned public service broadcaster and TV 2 as the commercial public service broadcaster). This is a convenience sample, comprising all Norwegian newspapers that followed the editorial poster (Nored, 2019), and had a continuously updated online news service at the time of sampling (2015-2017). The three national news media (NRK, TV 2 and Nettavisen), 
were included because they are major agenda setters (and NRK also has regional offices across the country) and as such, provide a benchmark for assessing content distribution within national/local content settings. This data has been collected manually from statistical, industry and government sources, as well as directly from the publishers and industry organisations.

The data was systematised and analysed using spreadsheets and the statistical program SPSS. Publishers are coded according to structural media systems variables, including whether or not the publisher receives press support; ownership (whether it is state owned or independently owned, i.e. neither part of a corporation or chain of newspapers, nor state owned); market competition (whether it is alone in the market, leading, or number two in the market); how many municipalities it covers; circulation, and number of editions per week. We also included time of publication, operationalised as scrape hour and scrape date (the point in time when articles were sampled, predominantly on an hourly basis), to check for seasonal fluctuations. Local political structure variables include population, location (longitude and latitude), unemployment rates and unemployment growth, and votes for incumbent. These variables were taken from the Local Government Dataset (Fiva et al., 2012), chosen to reflect characteristics embedded in the Norwegian political system, consisting of small dispersed communities, primarily operationalised as distance to the capital and population size. Unemployment and votes for incumbent were chosen to gauge how local labour market and political stability shape local political journalism in monopolistic market structures.

This sample consists of 15 national circulation media, ${ }^{1} 29$ metropolitan media with regional coverage beyond their head office location, ${ }^{2}$ and 112 local media ${ }^{3}$ (including 73 press supported newspapers ${ }^{4}$ ). National and regional news media were included to provide comparison between national and local content profiles. 26 of these publishers are independently owned (i.e. private, non-corporate), the rest are corporation-owned media, except for the public service broadcaster which is state owned.

The second dataset consists of 847,487 news articles collected from the digital editions of the same publishers, over three periods (October to December 2015 and 2016, and October 2017) using custom scrapers, including all subscription content (articles behind paywalls). An LDA (Blei et al., 2003) topic modelling analysis was performed on the articles to ascertain the distribution of topics in the corpus, from which an analysis of the political coverage could be gauged. LDA is a class of methods for characterising the hidden structure of large corpora unsupervised by human input beyond prompting a number of topics to be rendered. The LDA renders the desired set of topics based on the frequency with which words appear together in the corpus. As news discourse is a highly characteristic language, the LDA was able to present collections of words to which labels could be easily attached. A threshold for the likelihood that a document is actually about a certain topic was set based on Elgesem and colleagues (2016). We removed stop words based on a list of 314 manually selected words from among the most frequent words in the corpus, and used the MALLET tool (McCallum, 2002) to run the analysis.

We ran the model on 200 topics. This parameter was established by running a series of topic numbers, starting with five and ending with 300. The aim of this process was to establish the desired granularity needed for detailed analysis (cf. Jacobi et al., 2016; Maier et al., 2018), in terms of singularity (the extent to which the topic rendered a unified topic), and distinction (how different the topics were from each other) (see also 
Sjøvaag \& Pedersen, 2019). For each of the models, every topic was manually characterised by examining the 30 most informative words for each topic. These manual descriptions were subsequently verified by examining a selection of randomly assigned articles to the topics (cf. Elgesem et al., 2016; Jacobi et al., 2016; Maier et al., 2018). We adopted the heuristic of assigning to every document up to three topics (Elgesem et al., 2016) as follows: Identify the topic which most likely characterises the document, and all topics which are at least half as likely ( $50 \%$ as likely, or more, as the most likely topic). If this set of topics does not exceed three topics, we regard those as the topics of the document. If there are more than three likely topics, we consider the document to not pertain to any topic in particular.

As in any topic model, a number of topics will render indistinct topics consisting of associated words that make little sense as categories, even after stop word removal, such as mark-up language, abbreviations, time words or gender words. In our analysis, 20 such topics were identified (10\% of the model, an acceptable level). To the rest of the 180 topics, we were able to attach real world news labels. An example of such topic identification is topic 44, labelled "local politics", consisting of the following top words: AP (the Labour Party), mayor, municipal council, the case, the Conservative Party, FRP (the Progress Party), municipality, SP (the Centre Party), executive committee, politicians, proposal, SV (the Socialist Left Party), now, the meeting, KRF (the Christian Democratic Party), political, city council, Labour Party, Liberal Party, political, deputy mayor, proposal, believe, majority, councillor, leader, decision.

We then proceeded to group these 180 topics into overall topical news categories, which were again grouped into hard/soft news (see Figure A1 in the Appendix). The hard/soft categorisation was based on Lehman-Wilzig and Seletzky (2010), where hard news topics are defined as politics, economy and social issues. Important crime stories were included in the definition of hard news based on Reinemann and colleagues (2012) to account for the social relevance dimension as well as the immediacy and public safety aspects of online news. Hard news was singled out to allow specifically for testing journalism's political accountability function. Of these 180 topics, 33 were political topics, listed in Table 1. Political topics were again divided into politics in general, local politics and area politics. This was to distinguish between political coverage at the national level (general politics relating to the Government, Ministries and political parties); local politics (signified by political processes with clear reference to the municipality level); and what we have termed area politics - political issues on the agenda that were clearly defined in terms of policy area (e.g. army base location debates, and refugees crossing the northern border), and thus geography.

Note that topic categorisation says nothing about the type of articles found in the different publications. While one newspaper may carry a lot of political news, there is nothing in this analysis to distinguish long feature articles from press clippings or agency feeds. The operationalisation of the political topic into local, area and general politics does, however, inform the analysis. While general politics may be the subject of short press clippings, local politics rarely travel across publications, supporting the assumption that the local politics topics consist mainly of news articles. (Please see Note 1 in Appendix for further details regarding data description and methods. Table A1 and Figure A1 in the appendix present descriptive statistics and articles per topic and topic category, respectively.). 
Table 1. Political topics

\begin{tabular}{|c|c|c|}
\hline No. & Topic & Political sub-topic \\
\hline 26 & The parliament and members of parliament & National politics \\
\hline 60 & Negotiations to form Government & \\
\hline 73 & The national budget & \\
\hline 123 & The national budget & \\
\hline 133 & The Government and ministers & \\
\hline 193 & The Government and ministers & \\
\hline 188 & Political parties & \\
\hline 49 & Debate concerning the arming of police & \\
\hline 56 & Municipal reform & Area politics \\
\hline 69 & Islam, Muslims and Muslim immigration & \\
\hline 71 & Climate change and international agreement & \\
\hline 87 & Debate concerning closing the airport at Rygge & \\
\hline 164 & Syrian refugees crossing Norwegian borders & \\
\hline 177 & Norwegian defence, debate concerning the Andøya Base & \\
\hline 196 & Railway strike & \\
\hline 44 & Municipal councils & Local politics \\
\hline 126 & Municipal budgets & \\
\hline 183 & Municipal decisions & \\
\hline 194 & Municipal councils in Oslo and Bergen & \\
\hline 62 & The Syrian war & War/conflict \\
\hline 96 & Russia and Russian foreign politics & \\
\hline 103 & The Israel/Palestine conflict & \\
\hline 116 & Turkey and Turkish conflicts & \\
\hline 148 & War in the Middle East & \\
\hline 12 & Mulla Krekar's criminal status & Terrorism \\
\hline 143 & Terrorism in France & \\
\hline 3 & The EU and EU politics & International politics \\
\hline 8 & The Nobel Peace Prize & \\
\hline 83 & Brexit & \\
\hline 88 & Political elections around the world & \\
\hline 140 & Catalan independence & \\
\hline 154 & China and South-East Asia politics & \\
\hline 181 & The US presidential election & \\
\hline
\end{tabular}

Comment: Results from the LDA topic model including topic numbers, their topical label and corresponding political sub-topic. Note that some topics are present in more than one cluster.

\section{Results}

The analysis is operationalised into structural variables thought to provide insight into the relationship between local political structures, local press structures and political journalism, to ascertain to what extent local journalism meets community information needs through infrastructure, output and performance (see Napoli et al., 2017). The structural analysis explores systemic variables with a qualitative, observational method, while the regression analysis also includes structural variables. 


\section{Structural analysis}

Assessing infrastructure is complicated, particularly because the boundaries of 'the local' is largely defined by the publishers themselves (ibid), most notably through reach and coverage. Our main interest here is to establish how competition, concentration and monopolistic markets are distributed geographically. The analysis is therefore based on data on newspaper reach (based on their self-reported areas of coverage/sales), coded as municipality numbers, to map the location of editorial offices as well as overlapping markets. We thus formulate the following hypotheses:

H1: The Norwegian newspaper structure is characterised by monopolistic markets.

$\mathrm{H} 2$ : Monopolistic markets are more prevalent in remote, population-sparse areas of the country.

Of the 156 newspapers included in our sample, 102 are alone in their markets, without direct competition, amounting to 65 per cent of publishers surveyed. These are predominantly local newspapers with low circulation and publication frequencies. Many of the publishers in the sample $(67$, or $43 \%)$ cover only one municipality. The majority of publishers thus operate without competition, supporting $\mathrm{H} 1$, and serve more than one local political community.

When we look at how municipalities are covered, the analysis shows that $204 \mathrm{mu}-$ nicipalities, about half of the total number (422), are only served by one newspaper. This occurs mostly in the population-sparse areas of the country - in the municipalities in the north of Norway ${ }^{5}$, along the coast ${ }^{6}$, and in inland areas ${ }^{7}$. These could be characterised as remote or rural areas consisting of small municipalities with low population figures located far from the centres of power. The counties where dual coverage is present in more than half of municipalities are those with population concentration. ${ }^{8}$ These could be characterised as predominantly capital-adjacent areas or regional population concentrations closer to the centres of power. Given this descriptive analysis, population size has an impact, as expected, on the level of competition in publisher markets. To that end, larger political units also receive more coverage. The mapping of the distribution of newspapers along the municipal political structure thus shows that there is a predictable centre/periphery effect, supporting H2. Markets with more audiences, and markets with more political power, have more journalistic coverage and a larger plurality of publishers. The question then becomes what these structural differences entail for political coverage.

\section{Regression analysis}

To find out how media systems variables play out at the local level, we focus on the relationship between the press structure, the political structure and political journalism, operationalised through LDA topic modelling.

We organise our analysis in several stages, beginning with bivariate regressions and continuing by including additional covariates to test the robustness of significant bivariate relationships. The second stage includes all covariates at the newspaper or municipality level, and the third stage includes all covariates with significant coefficients in the first and second stage of the analysis. There are two reasons for choosing this approach: 1) previous research indicates a high number of variables that may explain 
topic prevalence in newspapers; and 2) we do not have enough observations to analyse all variables simultaneously with sufficient statistical power (i.e., almost all coefficients would be non-significant, which we interpret as an indication of type II error).

The dependent variable in the regression analyses is the average of the share of articles in each newspaper that concern specific topics (ranging from 0 to 1). Further details regarding data and analyses are available in the appendix.

To test the relationship between infrastructure, output and performance, we formulate the following hypotheses:

H3: Press support leads to higher levels of political news coverage. This assumption is based on policy aims (Meld.St. 17 (2018-2019)) to sustain journalistic functions in all parts of the country.

H4: Remote location affects political news coverage positively. This is based on centre/periphery characteristics of the political structure (Rokkan, 1967) and the role of local news for political representation in the overall system.

H5: Monopolistic markets lead to lower levels of political news coverage. This assumption is based on prior research showing that competition has a positive effect on political news coverage (Gentzkow \& Shapiro, 2008).

H6: A publisher's size - meaning its reach, circulation and publication frequency affects political news positively. This is based on assumptions that more resources lead to more political coverage.

H7: Political news makes up a substantial part of news coverage overall. This assumption is based on prior analyses of the Norwegian news media landscape where political news tends to make up around 20 per cent of the content overall (Sjøvaag \& Pedersen, 2019).

H8: Independent ownership leads to lower levels of political news coverage. This is based on the assumption that independent publishers have fewer resources and thus less political coverage.

H9: Local political system characteristics indicating labour market and political stability (operationalised as unemployment rates and votes for incumbent) have a positive effect on the amount of political journalism. This assumption is based on the watchdog characteristics of local journalism (Firmstone \& Coleman, 2014), which should indicate that communities with high unemployment rates and low incumbency success are served by a higher amount of hard news.

H3 and H4 investigate the infrastructure dependency of local information needs (i.e. the availability of sources), H5 and H6 interrogate the output dependency (i.e. the quantity of news on offer), and $\mathrm{H} 7$ and $\mathrm{H} 8$ test the performance indicator (i.e. the quality of content, operationalised as the amount of political coverage) (cf. Napoli et al., 2017). H9 tests the significance of community structure on hard news journalism.

Tables A2-A5 in the appendix present the results of the initial steps in the analysis. Here, we summarise the main findings of these models. For the municipality variables, we only find significant effects of population and longitude, which associate positively with the prevalence of most topic categories (the exception is a non-significant relation- 
ship between population and local politics). Regarding publisher variables, press support appears to influence only area politics by itself, but it has significant effects on several topic categories in interaction with circulation (interactions are discussed in further depth below). Independent ownership influences only local politics. State ownership affects hard news and politics. Being alone in the market, and covering multiple municipalities, are not significant predictors of any topic category. The same goes for the frequency of publication and the size of circulation. Finally, the interactions between press support, on the one hand, and circulation and publication frequency, are significant in most models.

Table 2. Multivariate regression models

\begin{tabular}{|c|c|c|c|c|c|c|}
\hline \multirow[b]{2}{*}{ Press support } & \multirow{2}{*}{$\begin{array}{c}\text { Hard news } \\
-0.020\end{array}$} & \multicolumn{2}{|c|}{ Politics } & \multirow{2}{*}{$\begin{array}{c}\text { Local politics } \\
0.001\end{array}$} & \multicolumn{2}{|c|}{ Area politics } \\
\hline & & -0.017 & -0.029 & & $-0.012^{\star \star \star}$ & $-0.012^{\star \star}$ \\
\hline & $(0.026)$ & $(0.019)$ & $(0.018)$ & $(0.003)$ & $(0.004)$ & $(0.005)$ \\
\hline \multirow[t]{2}{*}{ Independent } & & 0.009 & 0.006 & $-0.015^{\star \star \star}$ & & \\
\hline & & $(0.018)$ & $(0.016)$ & $(0.003)$ & & \\
\hline \multirow[t]{2}{*}{ State owned (NRK) } & 0.026 & 0.023 & 0.008 & $-0.009^{\star \star \star}$ & 0.000 & $-0.016^{\star \star \star}$ \\
\hline & $(0.023)$ & $(0.030)$ & $(0.024)$ & $(0.003)$ & $(0.005)$ & $(0.004)$ \\
\hline \multirow[t]{2}{*}{ Circulation } & & -0.023 & -0.010 & 0.004 & $-0.012^{*}$ & \\
\hline & & $(0.023)$ & $(0.020)$ & $(0.003)$ & $(0.007)$ & \\
\hline \multirow[t]{2}{*}{ Editions per week } & -0.015 & 0.009 & -0.014 & 0.001 & & -0.009 \\
\hline & $(0.026)$ & $(0.021)$ & $(0.019)$ & $(0.003)$ & & $(0.006)$ \\
\hline \multirow{2}{*}{$\begin{array}{l}\text { Press support* } \\
\text { Circulation }\end{array}$} & & $0.073^{\star \star \star}$ & & $-0.017^{\star \star *}$ & $0.056^{\star \star \star}$ & \\
\hline & & $(0.022)$ & & $(0.004)$ & $(0.007)$ & \\
\hline \multirow{2}{*}{$\begin{array}{l}\text { Press support* } \\
\text { Editions per week }\end{array}$} & 0.066 & & $0.096^{\star \star \star}$ & & & 0.021 \\
\hline & $(0.046)$ & & $(0.036)$ & & & $(0.017)$ \\
\hline \multirow[t]{2}{*}{ Scrape hour } & $0.084^{*}$ & $0.050^{\star}$ & 0.034 & $0.008^{*}$ & & \\
\hline & $(0.045)$ & $(0.027)$ & $(0.028)$ & $(0.005)$ & & \\
\hline \multirow[t]{2}{*}{ Scrape hour^²} & -0.003 & $-0.002^{*}$ & -0.001 & -0.000 & & \\
\hline & (0.002) & $(0.001)$ & $(0.001)$ & $(0.000)$ & & \\
\hline \multirow[t]{2}{*}{ Unemployment growth } & & -0.829 & -0.725 & & -0.124 & -0.161 \\
\hline & & $(1.103)$ & $(1.072)$ & & $(0.425)$ & $(0.423)$ \\
\hline \multirow[t]{2}{*}{ Population } & $0.000^{\star \star \star}$ & $0.000^{\star \star \star}$ & $0.000^{\star \star \star}$ & $0.000^{\star \star \star}$ & $0.000^{\star \star \star}$ & $0.000^{\star \star \star}$ \\
\hline & $(0.000)$ & $(0.000)$ & $(0.000)$ & $(0.000)$ & $(0.000)$ & $(0.000)$ \\
\hline \multirow[t]{2}{*}{ Latitude } & 0.005 & 0.004 & 0.003 & & -0.000 & -0.001 \\
\hline & $(0.004)$ & $(0.003)$ & $(0.003)$ & & $(0.001)$ & $(0.001)$ \\
\hline \multirow[t]{2}{*}{ Longitude } & $0.011^{\star \star \star}$ & $0.006^{\star \star}$ & $0.006^{\star \star *}$ & $0.001^{\star * *}$ & $0.004^{\star \star \star}$ & $0.004^{\star \star \star}$ \\
\hline & $(0.004)$ & $(0.002)$ & $(0.002)$ & $(0.000)$ & $(0.001)$ & $(0.001)$ \\
\hline \multirow[t]{2}{*}{ _cons } & $-0.680^{\star \star}$ & $-0.484^{\star \star}$ & -0.324 & $-0.041^{*}$ & 0.019 & 0.042 \\
\hline & $(0.335)$ & $(0.207)$ & $(0.231)$ & $(0.025)$ & $(0.057)$ & $(0.059)$ \\
\hline$r^{2}$ & 0.403 & 0.440 & 0.462 & 0.247 & 0.383 & 0.353 \\
\hline $\mathrm{N}$ & 156 & 156 & 156 & 156 & 156 & 156 \\
\hline
\end{tabular}

${ }^{*} p<0.1,{ }^{* *} p<0.05,{ }^{* * *} p<0.01$

In the regression models presented in Table 2, predictors that have non-significant coefficients in both the bivariate and multivariate models have been removed, and the remaining municipality and publisher predictors are included simultaneously. For 'hard news' this leads to zero significant effects among the publisher-level predictors, whereas population and longitude exert significant effect. For 'politics', both interaction effects are significant. Moreover, population and longitude are the only significant predictors 
of the politics category besides the integration terms. Figure 1 examines the interaction more closely. For 'local politics' there are significant negative effects of independent and state ownership, whereas population and longitude exert significant positive effects. Finally, the models gauging 'area politics' indicate that the interaction between press support and circulation is a better predictor than the interaction between press support and editions per week. Again, population and longitude exert considerable positive effects also on 'area politics' as a topical category.

Figure 1. Interaction effects
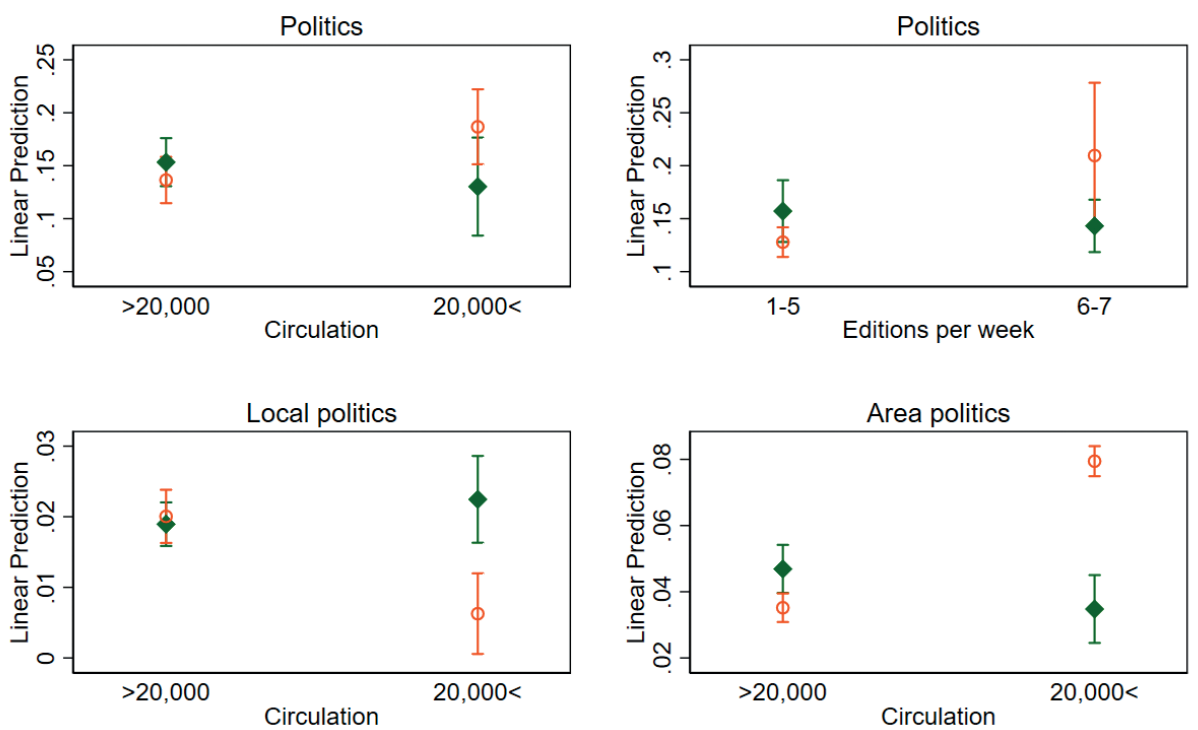

Figure 1 illustrates the interaction effects that are significant according to Table 2. For 'politics', the interaction is driven by newspapers without press support, where publishers with lower circulation and publication frequency report hard news less frequently. Local politics, however, displays a different pattern, although this effect is also driven by publishers without press support, in that publishers with a higher frequency of publication tend to write less frequently about local politics. Yet, this difference is relative since publishers with higher frequency have a higher number of articles and might therefore write more about local politics in absolute numbers (even though their share of local news stories is lower). For 'area politics', publishers without press support are again driving the effect, and publishers with higher circulation write more frequently about these topics as well. Considering the robustness tests, presented in Tables A6-A7 in the appendix, the interaction between press support and frequency of publication is driven by articles that mainly vary at the article level, but results are otherwise stable.

In sum, about half of our hypotheses were supported. As for the role of press support (H3), this has little effect on its own. In fact, the lack of press support seems to improve 
the amount of political reporting as publishers become larger. Remote location (H4) does affect political news coverage significantly. While state-induced infrastructure policy does not affect the availability of sources, the geo-political structure does. Hence, press system variables have little effect, while political system variables do have an effect. The quantity of news is not affected by monopolistic market structures (H5), but publisher size (publication frequency and circulation) (H6) does, predictably, affect the quantity of news, save for local political coverage, where large publishers perform worse than small publishers. To that end, media systems variables (i.e. the structure of newspaper markets) do seem to affect political news coverage. As for the quality of news, operationalised as the amount of hard, political news on offer, political news makes up 21 per cent of the content - the largest content category rivalled only by sports - indicating that the Norwegian news media landscape contains a good amount of political news coverage overall (H7). Forms of ownership (H8) do appear to influence journalism, as independent ownership has a negative effect on the amount of local politics. Finally, political system variables (H9), operationalised as geographical and demographic centre/ periphery factors, do have strong effects. Incumbency support or unemployment rates/ growth do not appear to affect the amount of hard news journalism in local communities. However, while publisher size is an indication of more hard news, centralisation is not equally predictive, as publishers in the north and thus more remote parts of the country perform better on the frequency of all hard news topics. This seems to support political structure influence on local political journalism. Lastly, seasonal fluctuations (tested for using scrape date) did not impact on topic distribution, which adds to our confidence in the estimated effects.

\section{Discussion}

Our analysis shows that the local media system is shaped by the geography of the Norwegian political landscape. Distance and size both have an effect on local journalism's community and accountability function. To that end, certain aspects of the political structure can be seen to shape the infrastructure of local news, such as location and municipality size. Other features of the political system that are also embedded into the media system, particularly regulation of media ownership structures and state press support, do not appear to have an effect. To that end, local subsystems (Christians et al., 2010) clearly play a role within the national setting. Given that markets are largely monopolistic, small and remote, the proximity between journalist, sources and the public (Guimera et al., 2018) form a 'microcosmos' that helps explain why small, local newspapers seem to survive in the Norwegian media system (cf. Newman et al., 2019). The local political coverage provided by small publishers could also help explain why audiences seem to trust and value their local news sources (Costera Meijer \& Bijleveld, 2016; SSB, 2018), arguably making local publishers 'keystone' media (Nielsen, 2015) in local public spheres serving local democracy (Hess \& Waller, 2016). However, printoriented local newspapers are predominantly read by older audiences. If sustaining the local publisher structure in Norway requires a shift towards more digital publication to ensure private operators can serve audiences alongside the regional structures of the public service broadcaster, this seems to suggest a need for additional resources. Such resources are more readily found in news corporations or newspaper chains, some of 
whom have begun to acquire more small, local newspapers in recent years (e.g. Amedia in Norway and Bonnier in Sweden).

One aspect of the Norwegian media system that one would expect to impact on local journalism structures is the welfare state-embedded regulations that are intended to support publicist infrastructures (cf. Syvertsen et al., 2014). Yet, the analysis shows that press support does not matter for local political coverage. Neither do monopolistic market structures affect how much news is published. In addition, corporatisation seems to be good for local political journalism. This points to questions regarding competition and ownership as grounds for mobilising regulatory instruments. It also raises issues as to their function as variables in analyses of media system differences and journalism's accountability function. Market variables, therefore, likely mean less for media system analyses at the local level than journalistic professionalism (making journalism more homogenous (cf. Benson, 2018)) and localism characteristics (contributing to differentiate journalism (cf. Sjøvaag et al., 2018)). On the other hand, the presence of NRK's regional offices points to the public service broadcaster playing a positive role in hard news and political journalism at the local level. The role of NRK thus indicates that press structures and public broadcasting structures should indeed be analysed in conjunction in media systems where these operate together.

Nevertheless, this study seems to confirm central characteristics of Norway as a democratic corporatist media system at the local level, particularly professional journalistic attitudes (covering hard news), and localism (covering local politics) (cf. Leupold et al., 2018). As demographic and geographic factors seem to be key also for political accountability functions in Norway (cf. Funk \& McCombs, 2017), the analysis supports the centre/periphery dimension in the Scandinavian media systems identified by Hallin and Mancini (2012). This study thus contributes to substantiate the importance of subsystems or the microcosmos within national media systems, and the role that these play in explaining local publisher structures and how these evolve. Analysing local news structures can thus aid in identifying the aspects that produce differences and similarities within and between media systems (cf. Hardy, 2008).

\section{Conclusions}

In sum, findings suggest that hard news reporting, in its various forms, is largely unaffected by the structures intended to encourage political journalism at the local level. To that end, regulation to ensure news coverage across a dispersed political structure - including press support, competition and ownership diversity - has little effect on the amount of political coverage of a given area. Instead, geographical and demographic factors have strong effects, indicating that local political structures are indeed reflected in the local media structure. Publishers that are located further north, as well as publishers located in municipalities with larger populations appear to write more frequently about hard news, politics, local politics and area politics. One structural effect is demonstrated, however, although not as expected: Press support has an indirect effect on news reporting only if considered in interaction with volume and frequency of publication. Publishers who do not receive press support appear to write more about hard news as they become larger. 


\section{Implications, limitations and further research}

The findings from this study imply that analysing local media systems characteristics can add to the analytical toolbox of media systems research. Not only can such subsystem analyses help to substantiate national-level models, they also enable researchers to refine how media systems analyses are operationalised. While this study mobilised the assessment approach provided by Napoli and colleagues (2017), there is still work to be done in operationalising the relationship between local political structures and local media structures. While such operationalisations should be grounded in media system variables, there might be considerable difference between media systems that require local adjustments of these assessment approaches. This study therefore comes with its own set of limitations, most notably embedded in its methodology and operationalisation. As the operationalisation is anchored in an assessment context taken from the American liberal media system, certain media system aspects are largely overlooked, such as political parallelism, levels of commercialisation and rational-legal authority. To that end, comparative research of local journalism structures should contribute to substantiate media systems models across different countries. Further research should also consider testing the conclusions drawn in this analysis with design-based methods as we only provide correlation evidence.

\section{Funding}

This research was supported by the Research Council of Norway under grant [230744].

\section{Notes}

1. Aftenposten, Dag og Tid, Dagbladet, Dagens Næringsliv, Dagsavisen, Fiskeribladet Fiskaren, Klassekampen, Morgenbladet, Nationen, Nettavisen, NRK, Ny Tid, TV 2, VG and Vårt Land.

2. Adresseavisen, Agderposten, Avisa Nordland, Bergensavisen, Bergens Tidende, Budstikka, Drammens Tidende, Fædrelandsvennen, Fredrikstad Blad, Gudbrandsdølen Dagningen, Glåmdalen, Hamar Arbeiderblad, Harstad Tidende, Haugesunds Avis, iTromsø, Moss Avis, Nordlys, Oppland Arbeiderblad, Rogalands Avis, Romerikes Blad, Romsdals Budstikke, Sandefjord Blad, Sarpsborg Arbeiderblad, Stavanger Aftenblad, Sunnmørsposten, Telemarks Avis, Tønsberg Blad, Varden and Østlandsposten.

3. Akers Avis Groruddalen, Akershus Amtstidende, Altaposten, Andøyposten, Arbeidets Rett, Arendals Tidende, Askøyværingen, Aura Avis, Aust-Agder Blad, Avisa Hemnes, Avisa Hordaland, Avisa Nordhordland, Avisa Sør-Trøndelag, Avisa Valdres, Avisen Agder, Bladet Vesterålen, Brønnøysunds Avis, Bygdanytt, Bygdebladet Randaberg, Bygdeposten, Bømlo-Nytt, Dalane Tidende, Demokraten, Dølen, Driva, Eidsvoll-Ullensaker Blad, Eikerbladet, Enebakk Avis, Fanaposten, Firda, Firdaposten, Fjell-Ljom, Fjordenes Tidene, Fjordingen, Fosnafolket, Framtid i Nord, Fremover, Gjengangeren, Gjesdalbuen, Grannar, Grenda, Grimstad Adressetidende, Hallingdølen, Hadeland, Halden Arbeiderblad, Hardanger Folkeblad, Helgelands Blad, Helgelendingen, Hitra-Frøya, Hålogalands Avis, iFinnmark, Indre Akershus Blad, Innherreds Folkeblad og Verdalingen, Jarlsberg Avis, Jærbladet, Kragerø Blad, Kvinnheringen, Kyst og Fjord, Laagendalsposten, Lierposten, Lillesandsposten, Lofotposten, Lokalavisa Nordsalten, Lyngdals Avis, Malvikbladet, Møre-Nytt, Namdalsavisa, Norddalen, Nordre, Nordstrands Blad, Nye Troms, Opdalingen, Porsgrunns Dagblad, Rana Blad, Rakkestad Avis, Ringerikets Blad, Ringsaker Blad, Røyken og Hurum Avis, Sagat, Saltenposten, Sande Avis, Sandnesposten, Smaalenenes Avis, Sogn Avis, Solabladet, Stjørdalens Blad, Strandbuen, Suldalsposten, Sunnhordland, Sunnmøringen, Svelvikposten, Sør-Varanger Avis, Telen, Tidens Krav, Troms Folkeblad, Trønderavisa, Trønderbladet, Tvedestrandsposten, Tysnes,

\section{Acknowledgements}

Thanks to Research Leader at Uni Research, NORCE Norwegian Research Centre, Dag Arne Christensen, for valuable input during the analysis. 
Tysvær Bygdeblad, Vaksdalsposten, Vennesla Tidende, Vestby Avis, Vestnesavisa, Vestnytt, Vikebladet Vestposten, Østlandets Blad, Østlendingen, Øyene, Ås Avis, Åndalsnes Avis, Åsane Tidende.

4. Note that this is an operational distinction. Newspapers that receive press support are mainly financed by subscription and/or sales revenue.

5. The counties of Finnmark and Nordland, where 95 and 67 per cent of municipalities, respectively, are covered by only one newspaper.

6. 58 per cent of municipalities in Møre \& Romsdal, 50 per cent in Sogn \& Fjordane and 73 per cent in Vest Agder are covered by only one paper.

7. Trøndelag (76\%), Oppland (65\%) and Østfold (61\%).

8. 33 per cent of the municipalities in Aust Agder county, 28 per cent of Telemark, 44 per cent of Vestfold, 33 per cent of Buskerud, 18 per cent of Hedmark, 33 per cent of Akershus, 25 per cent of Troms, 28 per cent of Hordaland, and 4 per cent of Rogaland are covered by only one newspaper.

9. Article-level data is aggregated by calculating the mean value of topic prevalence for each newspaper and by dropping duplicates.

\section{References}

Allern, S. \& Pollack, E. (2017). Journalism as a public good: A Scandinavian perspective. Journalism, doi: https://doi.org/10.1177/1464884917730945

Amedia (2018). Arsrapport 2017 [Annual report 2017]. Amedia. Retrieved from https://www.amedia.no/ globalassets/dokumenter/amedia-arsrapport-2017.pdf [accessed 2019, July 7].

Amedia (2019). Total mediehusdekning [Total media coverage]. Amedia. Retrieved from https://www.amediamarked.no/total-mediehusdekning [accessed 2019, July 7].

Benson, R. (2018). Can foundations solve the journalism crisis? Journalism, 19(8): 1059-1077.

Benson, R., Blach-Ørsten, M., Powers, M., Willig, I. \& Zambrano, S. V. (2012). Media systems online and off: Comparing the form of news in the United States, Denmark, and France. Journal of Communication, 62(1): 21-38.

Blei, D. M., Ng, A. \& Jordan, M. I. (2003). Latent Dirichlet allocation. Journal of Machine Learning Research. 3(Jan), 993-1022.

Bridges, J. A., Litman, B. R. \& Bridges, L. W. (2002). Rosse's model revisited: Moving to concentric circles to explain newspaper competition. The Journal of Media Economics, 15(1): 3-19.

Bruns, C. \& Himmler, O. (2011) Newspaper circulation and local government efficiency. Scandinavian Journal of Economics, 113(2), 470-492.

Christians, C. G., Glasser, T., McQuail, D., Nordenstreng, K. \& White, R. A. (2010). Normative theories of the media: Journalism in democratic societies. University of Illinois Press.

Costera Meijer, I. \& Bijleveld, H. P. (2016). Valuable journalism: Measuring news quality from a user's perspective. Journalism Studies, 17(7): 827-839.

Ekström, M., Johansson, B. \& Larsson, L. (2006). Journalism and local politics: A study of scrutiny and accountability in Swedish journalism. Journalism Studies, 7(2): 292-311.

Elgesem, D., Feinerer, I. \& Steskal, L. (2016). Bloggers' responses to the Snowden affair: Combining automated and manual methods in the analysis of news blogging. Computer Supported Cooperative Work (CSCW), 2(25): 167-191

Engan, B. (2016). Et informert valg? Offentlighet, patriotisme og pressens lokale samfunnsoppdrag [An informed choice? Publicness, patriotism and the local social contract of the press.] Norsk medietidsskrift, 23(2): 1-19.

Espeland, G. (2006). Lokalavisa ncer og kjæer [Local newspapers near and dear]. Oslo, Norway: Landslaget for lokalaviser.

Firmstone, J. \& Coleman, S. (2014). The changing role of the local news media in enabling citizens to engage in local democracies. Journalism Practice, 8(5): 596-606.

Fiva, J., Halse, A \& Natvik, G. J. (2012). Local government dataset. Dataset available at esop.uio.no.

Flew, T. \& Waisbord, S. (2015). The ongoing significance of national media systems in the context of media globalization. Media, Culture \& Society, 37(4): 620-636.

Funk, M. J. \& McCombs, M. (2017). Strangers on a theoretical train: Inter-media agenda setting, community structure, and local news coverage. Journalism Studies, 18(7): 845-865.

Gentzkow, M. \& Shapiro, J. M. (2008). Competition and truth in the market for news. Journal of Economic Perspectives, 22(2): 133-154.

Guimerà, J. À., Domingo, D. \& Williams, A. (2018). Local journalism in Europe: Reuniting with its audiences. Sur le journalisme, About journalism, Sobre journalism, 7(2): 4-11. Gulyas, A., O’Hara, S. \& Eilenberg, 
J. (2018). Experiencing local news online: Audience practices and perceptions. Journalism Studies, doi: https://doi.org/10.1080/1461670X.2018.1539345

Hallin, D. C. \& Mancini, P. (2004). Comparing media systems: Three models of media and politics. Cambridge: Cambridge University Press.

Hallin, D. C. \& Mancini, P. (2012). Conclusion. In D. C. Hallin \& P. Mancini (eds.), Comparing media systems beyond the Western world (pp. 278-304). Cambridge: Cambridge University Press.

Hanusch, F. (2015). A different breed altogether? Distinctions between local and metropolitan journalism cultures. Journalism Studies, 16(6): 816-833.

Hardy, J. (2008). Western media systems. London: Routledge.

Hess, K. (2015). Making connections: "Mediated" social capital and the small-town press. Journalism Studies, 16(4): 482-496.

Hess, K. \& Waller, L. (2016). Local journalism in a digital world. London: Palgrave.

Jacobi, C., Van Atteveldt, W. \& Welbers, K. (2016). Quantitative analysis of large amounts of journalistic texts using topic modelling. Digital Journalism, 4(1): 89-106.

Jenkins, J. \& Nielsen, R. K. (2018). The digital transition of local news. Reuters Institute for the Study of Journalism. Oxford: Oxford University.

Lacy, S. (1984). Competition among metropolitan daily, small daily and weekly newspapers. Journalism Quarterly, 61(3): 640-742.

Lehman-Wilzig, S. N. \& Seletzky, M. (2010). Hard news, soft news, 'general' news: The necessity and utility of an intermediate classification. Journalism, 11(1): 37-6.

Leupold, A., Klinger, U. \& Jarren, O. (2018). Imagining the city: How local journalism depicts social cohesion. Journalism Studies, 19(7): 960-982.

Lie, M. P. (2018). Local newspapers, Facebook and local civic engagement: A study of media use in two Norwegian communities. Nordicom Review, 39(2): 49-62

Livingstone, S. (2012). Challenges to comparative research in a globalizing media landscape. In F. Esser \& T. Hanitzsch (eds.), The handbook of comparative communication research (pp. 415-429). New York: Routledge.

Maier, D., Waldherr, A., Miltner, P., Wiedemann, G., Niekler, A., Keinert, A., ... \& Schmid-Petri, H. (2018). Applying LDA topic modeling in communication research: Toward a valid and reliable methodology. Communication Methods and Measures, 12(2-3): 93-118.

Mathisen, B. R. (ed.) (2010). Lokaljournalistikk: Blind patriotisme eller kritisk korrektiv? [Local journalism: Blind patriotism or critical corrective?]. Kristiansand, Norway: Høyskoleforlaget.

Mathisen, B. R. \& Molandstø, L. (2015). Regionale motstemmer i nasjonal offentlighet [Regional counter voices in the national public sphere]. Norsk Medietidsskrift, 22(4): 1-19.

McCallum, A. K. (2002). Mallet: A machine learning for language toolkit.

Meld.St. 17 (2018-2019). Mangfald og armlengdes avstand: Mediepolitikk for ei ny tid [Diversity and arm's length distance: Media policy for a new age]. Oslo: Ministry of Culture. Retrieved from https://www. regjeringen.no/no/dokumenter/meld.-st.-17-20182019/id2638833/sec3 [accessed 2019, August 5].

Napoli, P. M., Stonbely, S., McCollough, K. \& Renninger, B. (2017). Local journalism and the information needs of local communities: Toward a scalable assessment approach. Journalism Practice, 11(4): 373-395.

Newman, N., Fletcher, R., Kalogeropoulos, A. \& Nielsen, R. K. (2019). Reuters Institute digital news report 2019. Reuters Institute for the Study of Journalism, Oxford University.

Nielsen, R. K. (2015). Local newspapers as keystone media: The increased importance of diminished newspapers for local political information environments. In R.K. Nielsen (ed.), Local journalism: The decline of newspapers and the rise of digital media. London: Bloomsbury Publishing, 51-

Nord, L. W. (2007). Investigative journalism in Sweden: A not so noticeable noble art. Journalism, 8(5): $517-521$.

Nored (2019). Redaktørplakaten [The editorial poster] Nored. Retrieved from https://www.nored.no/Redaktoerplakaten/Redaktoerplakaten.[accessed 2019, July 7].

Oberholzer-Gee, F. \& Waldfogel, J. (2009). Media markets and localism: Does local news en Espanol boost Hispanic voter turnout? American Economic Review, 99(5): 2120-2128.

Ostini, J. \& Ostini, A. Y. (2002). Beyond the four theories of the press: A new model of national media systems. Mass Communication and Society, 5(1): 41-56.

Ots, M. (2009). Efficient servants of pluralism or marginalized media policy tools? The case of Swedish press subsidies. Journal of Communication Inquiry, 33(4): 376-392.

Powers, M., Zambrano, S. V. \& Baisnée, O. (2015). The news crisis compared: The impact of the journalism crisis on local news ecosystems in Toulouse (France) and Seattle (US). In R. K. Nielsen (ed.), Local journalism: The decline of newspapers and the rise of digital media (pp. 31-50). London: Bloomsbury Publishing. 
Reinemann, C., Stanyer, J., Scherr, S. \& Legnante, G. (2012). Hard and soft news: A review of concepts, operationalizations and key findings. Journalism, 13(2): 221-239.

Rokkan, S. (1967). Geography, religion, and social class: Crosscutting cleavages in Norwegian politics. In S. M. Lipset \& S. Rokkan (eds.), Party systems and voter alignments: Cross-national perspectives (pp. 379-386). New York: Free Press.

Rosse, J. N. (1975). Economic limits of press responsibility. Studies in Industry Economics, 56: 12-18.

Siebert, F., Peterson, T. B., Peterson, T. \& Schramm, W. (1956). Four theories of the press: The authoritarian, libertarian, social responsibility, and Soviet communist concepts of what the press should be and do. Urbana: University of Illinois Press.

Sjøvaag, H. \& Pedersen, T. A. (2019). Female voices in the news: Structural conditions of gender representations in Norwegian newspapers. Journalism \& Mass Communication Quarterly, 96(1): 215-238.

Sjøvaag, H., Pedersen, T. A. \& Owren, T. (2018). Is public service broadcasting a threat to commercial media?. Media, Culture \& Society, doi: https://doi.org/10.1177/0163443718818354.

Sjøvaag, H., Stavelin, E., Karlsson, M. \& Kammer, A. (2019). The hyperlinked Scandinavian news ecology: The unequal terms forged by the structural properties of digitalisation. Digital Journalism, 7(4): 507-531.

Skogerbø, E. \& Krumsvik, A. H. (2015). Newspapers, Facebook and Twitter: Intermedial agenda setting in local election campaigns. Journalism Practice, 9(3): 350-366.

Skogerbø, E. \& Winsvold, M. (2011). Audiences on the move? Use and assessment of local print and online newspapers. European Journal of Communication, 26: 214-229.

Slaatta, T. (2015). Print versus digital in Norwegian newspapers. Media, Culture \& Society, 37(1): 124-133.

SSB (2018). Norsk mediebarometer 2018 [Norwegian media survey 2018] Statistics Norway. Retrieved from https://www.ssb.no/kultur-og-fritid/artikler-og-publikasjoner/_attachment/384577?_ts=16a92faad18 [accessed 2019, July 7].

Syvertsen, T., Mjøs, O. J., Moe, H. \& Enli, G. S. (2014). The media welfare state: Nordic media in the digital era. Ann Arbor: University of Michigan Press.

Wadbring, I. \& Bergström, A. (2017). A print crisis or a local crisis? Local news use over three decades. Journalism Studies, 18(2): 175-190. 


\section{Appendix}

\section{Note 1. Data description and details regarding analysis}

Figure A1 shows the distribution of political topics in the corpus along the hard/soft news distinction. Here, hard news is operationalised as politics, economy and social issues (cf. Lehman-Wilzig \& Seletzky, 2010), while soft news is operationalised as everyday life issues, crime, accidents, culture, traffic, sports and weather (cf. Reinemann et al., 2012). 'Other' issues constitute articles where the overall topic was determined by their use of the minority written language Nynorsk (rather than their topic), geographic topics consisting of place names in the same region, ambiguous content such as markup language and words that often occur together without rendering topical meaning (e.g. calendar words such as Monday, Thursday, August, etc.). 'Not coded' content constitutes articles that were not given a topic by the LDA algorithm, falling below the threshold established by Elgesem and colleagues (2016), essentially meaning that there were too many topics that the article was likely to be about to warrant categorisation. This 'not coded' category constitutes about 10 per cent of the corpus.

Figure A1. Articles per topic and topic category

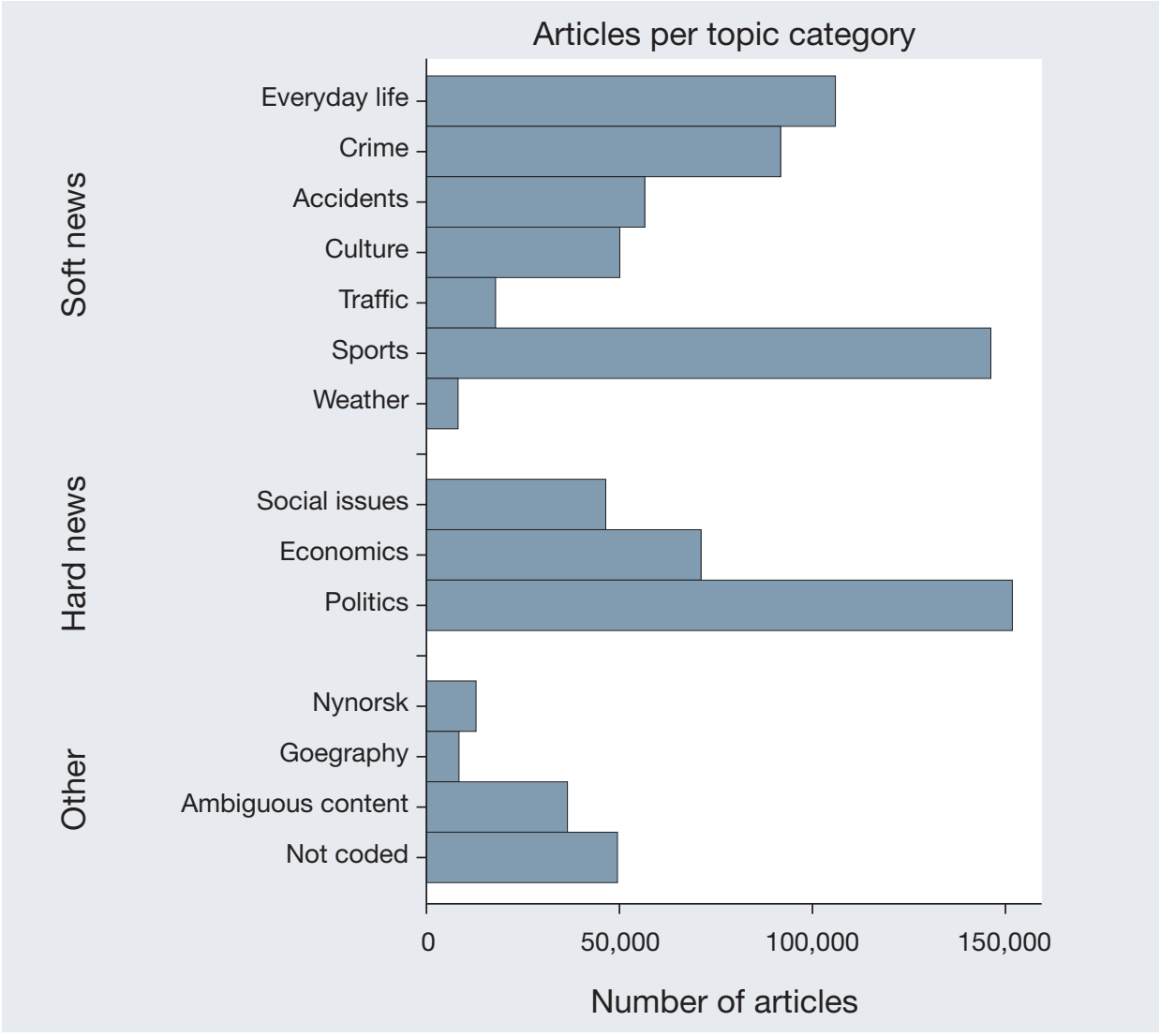


While the analysis renders ample information about the content of each news article in the corpus, there is little information in the data to explain variation across articles. Consequently, we aggregated article-level data to the publisher level, i.e. the media outlets in which the articles were published ${ }^{9}$. Because this leads to a loss of information, it is only appropriate to focus on the aggregate level if the content varies substantially between publishers (Rabe-Hesketh \& Skrondal, 2008). Figure A2 illustrates interclass correlations (ICC) of topics within all the topics, hard news topics, political topics, and local and area politics, interpreted as the amount of article content that varies between publishers. The boxes indicate 25-75 percentiles; the line within the box represents the media; the capped spikes indicate upper and lower adjacent values, and dots represent outliers.

Figure A2. Box plots of weighted and unweighted interclass correlations for selected topic categories

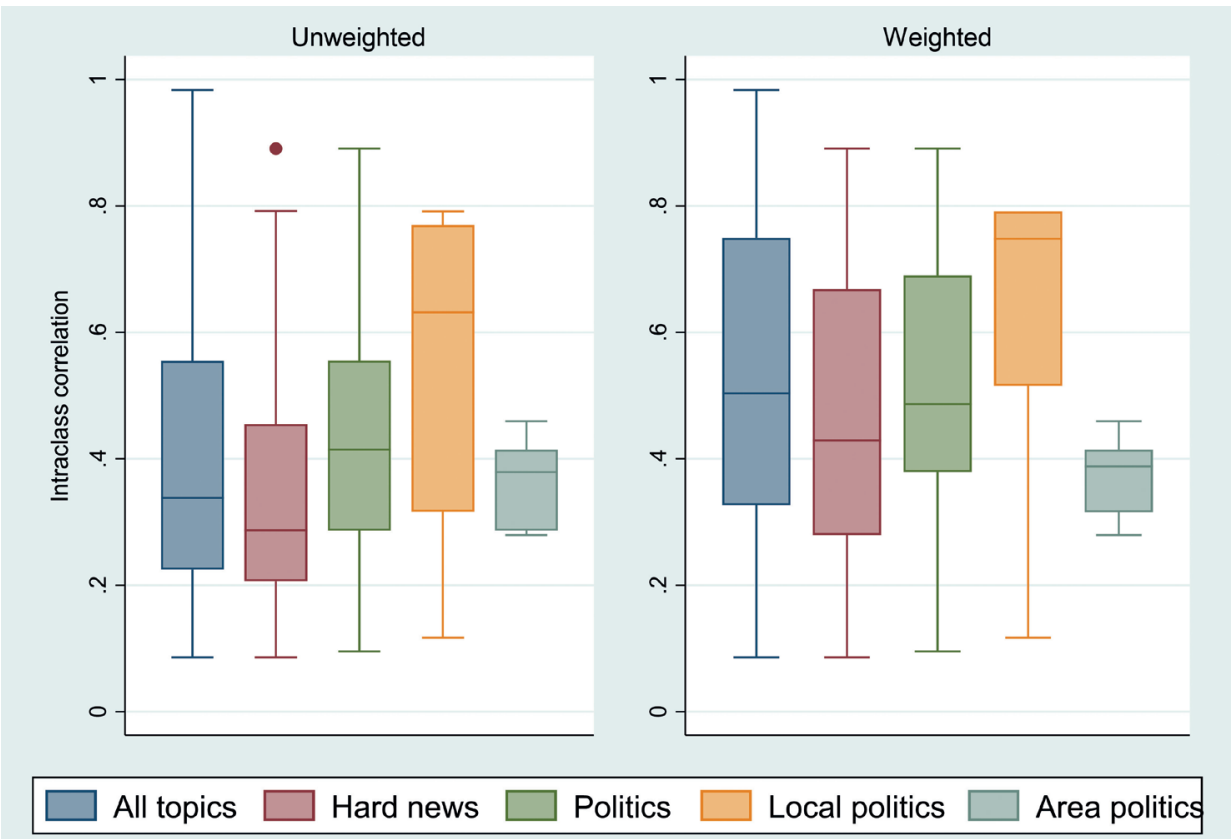

Figure A2 shows that approximately 40 per cent of the variation in article content occurs at the level of publishers when gauging 'all topics'. The corresponding ICCs of hard news topics are slightly lower, but higher for political and local political topics. Moreover, the range of ICCs is high for topics within all categories except 'area politics' (political coverage of a particular topical case). The variation of topics ranges from approximately 10-100 per cent at the publisher level. The right-hand panel illustrates ICC statistics weighted by themselves (i.e. higher values count more). The analysis includes robustness tests where the dependent variables are substituted with ICC-weighted dependent variables, the purpose of which is to examine if results are driven by topics that vary a lot between articles, irrespective of where they were published. 
Figure A3 and Table A1 give an impression of what the data looks like after aggregation. Units constitute 'publishers' (media outlets), while dependent variables constitute 'shares of articles covering respective topic categories'. Independent variables constitute descriptive publisher values and municipality values where the news offices are located. As the dependent variables range from 0 to 1 and the distribution of values is left-skewed, fractional regression is recommended to obtain unbiased estimates (Wooldridge, 2010). For ease of interpretation, ordinary least squares (OLS) regression is presented in the main text, while fractional regressions are included as an appendix constituting robustness tests.

Figure A3. Histogram of selected topic categories
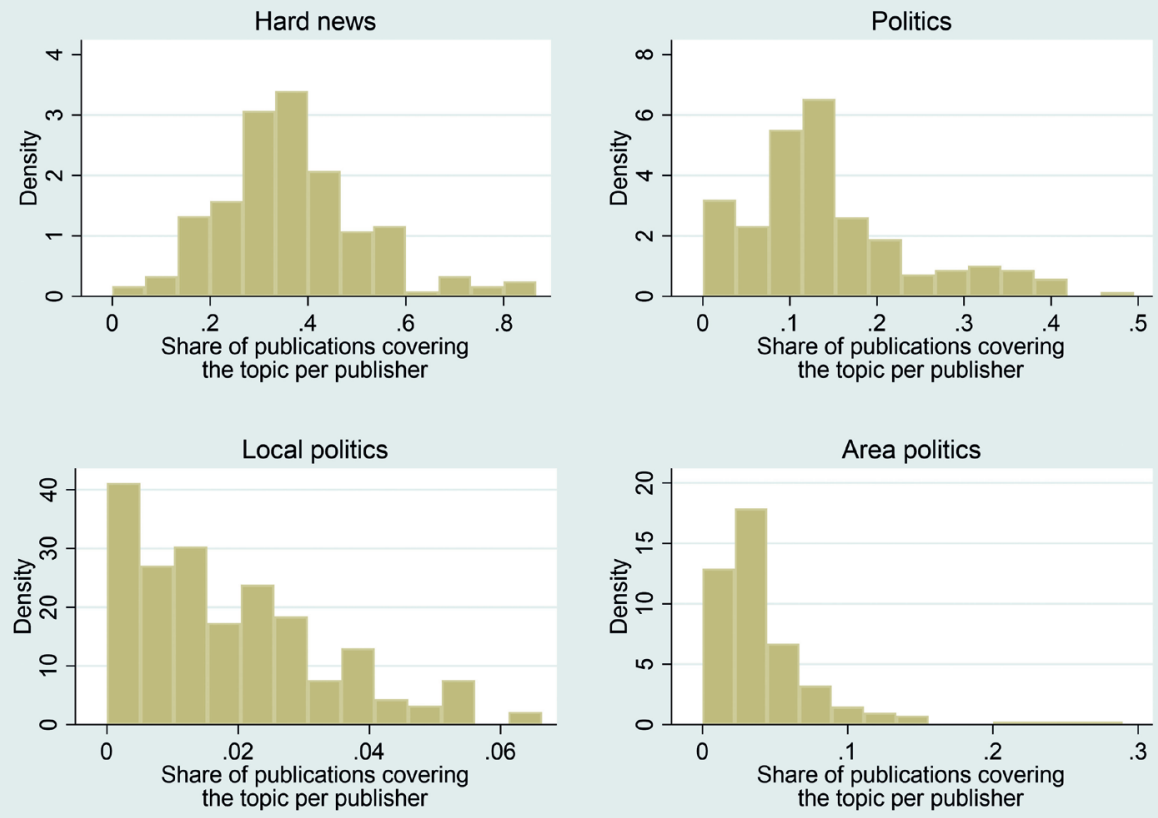
Table A1. Descriptive statistics

\begin{tabular}{|c|c|c|c|c|c|}
\hline Dependent variables & N & Mean & SD & Min & Max \\
\hline Hard news & 181 & 0.37 & 0.15 & 0.00 & 0.87 \\
\hline Politics & 181 & 0.14 & 0.10 & 0.00 & 0.50 \\
\hline Local politics & 181 & 0.02 & 0.02 & 0.00 & 0.07 \\
\hline Hard news (ICC adjusted) & 181 & 0.37 & 0.15 & 0.00 & 0.87 \\
\hline Politics (ICC adjusted) & 181 & 0.05 & 0.05 & 0.00 & 0.21 \\
\hline Hard news (ICC adjusted) & 181 & 0.37 & 0.15 & 0.00 & 0.87 \\
\hline Independent variables: Publisher-level & N & Mean & SD & Min & Max \\
\hline Press support & 181 & 0.44 & 0.50 & 0.00 & 1.00 \\
\hline Independent & 181 & 0.29 & 0.46 & 0.00 & 1.00 \\
\hline State owned (NRK) & 186 & 0.01 & 0.07 & 0.00 & 1.00 \\
\hline Circulation $>20 \mathrm{k}$ & 181 & 0.17 & 0.38 & 0.00 & 1.00 \\
\hline Editions per week $>5$ & 181 & 0.28 & 0.45 & 0.00 & 1.00 \\
\hline Alone in the market & 181 & 0.57 & 0.50 & 0.00 & 1.00 \\
\hline Municipalities covered $>2$ & 164 & 0.50 & 0.50 & 0.00 & 1.00 \\
\hline Scrape date & 181 & 20659.86 & 127.26 & 20367.00 & 21108.70 \\
\hline Scrape hour & 181 & 13.53 & 1.69 & 5.50 & 17.36 \\
\hline Independent variables: Municipality-level & N & Mean & SD & Min & Max \\
\hline Unemployment & 161 & 0.02 & 0.01 & 0.01 & 0.04 \\
\hline Unemployment growth & 161 & 0.00 & 0.00 & -0.01 & 0.02 \\
\hline Population & 161 & 97090.98 & $1.94 \mathrm{e}+05$ & 1330.50 & $6.53 e+05$ \\
\hline Latitude & 161 & 61.58 & 3.27 & 58.03 & 70.95 \\
\hline Longitude & 161 & 10.12 & 4.32 & 5.03 & 30.04 \\
\hline Votes for incumbent & 161 & 0.57 & 0.12 & 0.29 & 0.88 \\
\hline
\end{tabular}

Publisher variables were chosen to gauge the effect of media support, ownership, size and reach as well as market position on political news reporting. Municipal variables were chosen to test the significance of variables thought to have an effect on the amount of political coverage in a given area, such as unemployment and incumbent voting.

Data on newspaper publishers (including aggregated topic values) and municipality statistics were merged by including statistics of the municipalities where publishers' main offices are located. The municipality characteristics were taken from the Local Government Dataset (Fiva et al., 2012), which includes all municipalities covered in our sample, except Svalbard. The number of observations per municipality variable is inflated because several (clusters of) municipalities host more than one publisher, and because several publishers distribute to the same municipalities. This pertains in particular to the nationwide publishers, often located in the capital Oslo, whose reach includes all municipalities, which can lead to deflated standard errors in the regression for variables where these publishers have a high loading. This problem is alleviated by calculating clustered standard errors using a variable that identifies the publishers' main office municipalities. 


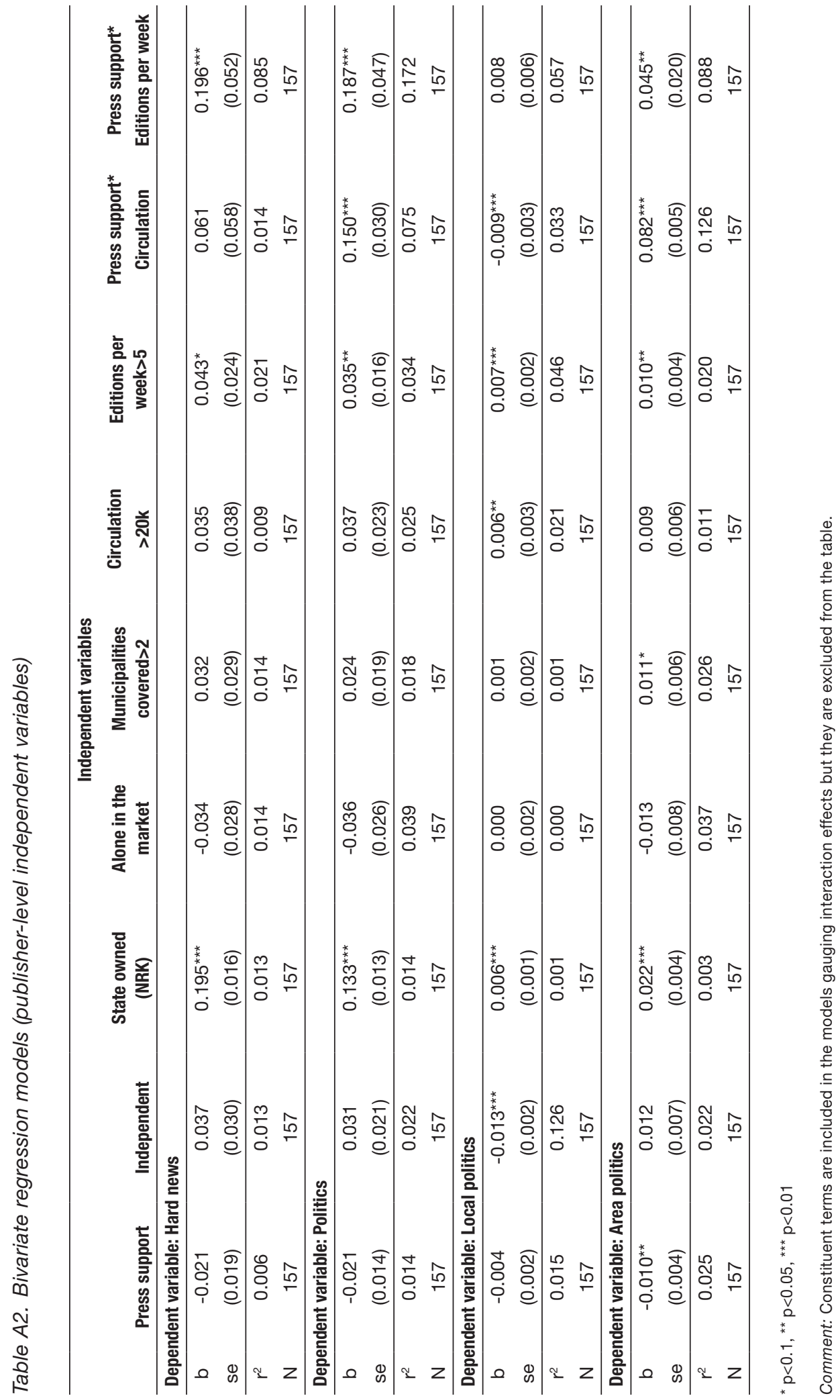


Table A3. Bivariate regression models (municipality-level independent variables)

\begin{tabular}{|c|c|c|c|c|c|c|}
\hline \multicolumn{7}{|c|}{ Independent variables } \\
\hline & Unemployment & $\begin{array}{l}\text { Unemployment } \\
\text { growth }\end{array}$ & Population & Latitude & Longitude & $\begin{array}{l}\text { Votes for } \\
\text { incumbent }\end{array}$ \\
\hline \multicolumn{7}{|c|}{ Dependent variable: Hard news } \\
\hline b & 0.315 & $-5.048^{\star}$ & $0.000^{\star \star \star}$ & $0.015^{\star \star \star}$ & $0.014^{\star \star \star}$ & 0.012 \\
\hline se & (1.980) & $(2.869)$ & $(0.000)$ & $(0.004)$ & $(0.003)$ & $(0.115)$ \\
\hline$r^{2}$ & 0.000 & 0.029 & 0.113 & 0.129 & 0.208 & 0.000 \\
\hline $\mathrm{N}$ & 156 & 156 & 156 & 156 & 156 & 156 \\
\hline \multicolumn{7}{|c|}{ Dependent variable: Politics } \\
\hline b & -0.522 & $-4.755^{\star *}$ & $0.000^{\star \star \star}$ & $0.008^{\star \star \star}$ & $0.009^{\star \star \star}$ & 0.008 \\
\hline se & (1.313) & (2.020) & $(0.000)$ & $(0.003)$ & $(0.002)$ & $(0.089)$ \\
\hline$r^{2}$ & 0.001 & 0.061 & 0.205 & 0.087 & 0.178 & 0.000 \\
\hline $\mathrm{N}$ & 156 & 156 & 156 & 156 & 156 & 156 \\
\hline \multicolumn{7}{|c|}{ Dependent variable: Local politics } \\
\hline b & 0.066 & -0.278 & $0.000^{* *}$ & 0.000 & $0.001^{*}$ & -0.000 \\
\hline se & $(0.182)$ & $(0.215)$ & $(0.000)$ & $(0.000)$ & $(0.000)$ & $(0.010)$ \\
\hline$r^{2}$ & 0.001 & 0.007 & 0.007 & 0.001 & 0.028 & 0.000 \\
\hline $\mathrm{N}$ & 156 & 156 & 156 & 156 & 156 & 156 \\
\hline \multicolumn{7}{|c|}{ Dependent variable: Area politics } \\
\hline$b$ & -0.309 & $-1.886^{\star \star \star}$ & $0.000^{\star \star \star}$ & $0.003^{\star \star \star}$ & $0.004^{\star \star \star}$ & -0.017 \\
\hline se & $(0.484)$ & $(0.691)$ & $(0.000)$ & $(0.001)$ & $(0.001)$ & $(0.025)$ \\
\hline$r^{2}$ & 0.003 & 0.070 & 0.090 & 0.080 & 0.228 & 0.004 \\
\hline $\mathrm{N}$ & 156 & 156 & 156 & 156 & 156 & 156 \\
\hline
\end{tabular}

$* \mathrm{p}<0.1, * * \mathrm{p}<0.05, * * * \mathrm{p}<0.01$ 


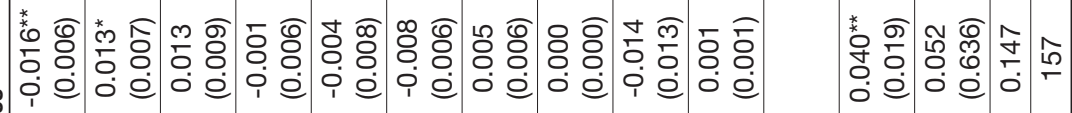
흔

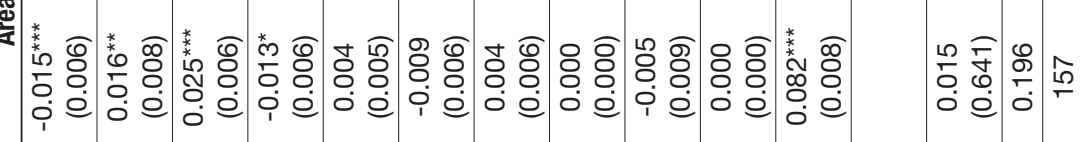

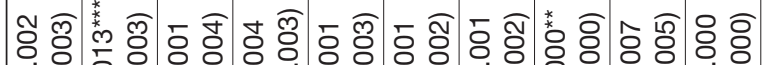
\&

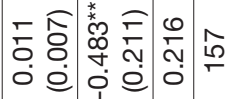
흠 o e

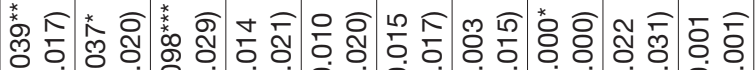
i é

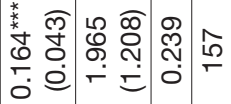

능

สิ

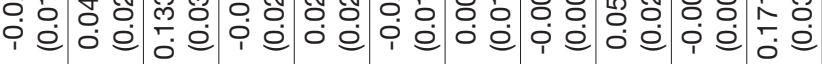

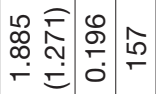

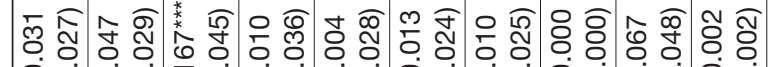
焉 i é 0 e

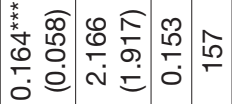
工

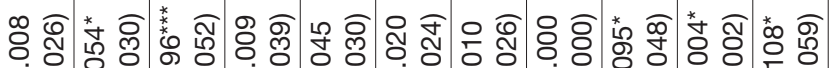
i

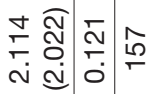


Journalism and the political structure: The local media system in Norway

Table A5. Multivariate regression models (municipality-level independent variables)

\begin{tabular}{lcccc}
\hline & Hard news & Politics & Local politics & Area politics \\
\hline Unemployment & 1.502 & -0.082 & 0.020 & -0.128 \\
& $(1.617)$ & $(0.858)$ & $(0.188)$ & $(0.426)$ \\
\hline Unemployment growth & 0.276 & -0.825 & 0.020 & -0.188 \\
& $(2.360)$ & $(1.280)$ & $(0.242)$ & $(0.453)$ \\
\hline Population & $0.000^{\star \star \star}$ & $0.000^{\star \star \star}$ & 0.000 & $0.000^{\star \star \star}$ \\
& $(0.000)$ & $(0.000)$ & $(0.000)$ & $(0.000)$ \\
\hline Latitude & $0.008^{\star}$ & 0.003 & $-0.001^{\star \star}$ & -0.001 \\
& $(0.004)$ & $(0.003)$ & $(0.001)$ & $(0.001)$ \\
\hline Longitude & $0.011^{\star \star \star}$ & $0.007^{\star \star \star}$ & $0.001^{\star \star \star}$ & $0.004^{\star \star \star}$ \\
& $(0.004)$ & $(0.002)$ & $(0.000)$ & $(0.001)$ \\
\hline Votes for incumbent & 0.129 & $0.111^{\star}$ & 0.007 & 0.017 \\
& $(0.088)$ & $(0.061)$ & $(0.010)$ & $(0.015)$ \\
\hline cons & -0.362 & -0.210 & $0.070^{\star \star}$ & 0.040 \\
& $(0.235)$ & $(0.150)$ & $(0.032)$ & $(0.063)$ \\
\hline $\mathrm{r}^{2}$ & 0.360 & 0.421 & 0.060 & 0.333 \\
\hline $\mathrm{N}$ & 156 & 156 & 156 & 156 \\
\hline
\end{tabular}

${ }^{*} p<0.1,{ }^{* *} p<0.05,{ }^{* * *} p<0.01$ 
Helle Sjøvaag, Truls André Pedersen \& Ole Martin Lægreid

Table A6. Robustness test with ICC-adjusted dependent variables

\begin{tabular}{|c|c|c|c|c|c|c|}
\hline \multirow[b]{2}{*}{ Press support } & \multirow{2}{*}{$\begin{array}{c}\text { Hard news } \\
-0.020 \\
(0.026)\end{array}$} & \multicolumn{2}{|c|}{ Politics } & \multirow{2}{*}{$\begin{array}{c}\begin{array}{c}\text { Local } \\
\text { politics }\end{array} \\
0.001 \\
(0.002) \\
\end{array}$} & \multicolumn{2}{|c|}{ Area politics } \\
\hline & & $\begin{array}{l}-0.004 \\
(0.009)\end{array}$ & $\begin{array}{l}-0.012 \\
(0.008)\end{array}$ & & $\begin{array}{c}-0.004^{\star \star \star} \\
(0.001)\end{array}$ & $\begin{array}{c}-0.004^{\star *} \\
(0.002)\end{array}$ \\
\hline Independent & & $\begin{array}{l}0.005 \\
(0.010)\end{array}$ & $\begin{array}{c}0.004 \\
(0.009)\end{array}$ & $\begin{array}{c}-0.010^{\star \star \star} \\
(0.002)\end{array}$ & & \\
\hline $\begin{array}{l}\text { State owned } \\
\text { (NRK) }\end{array}$ & $\begin{array}{c}0.026 \\
(0.023)\end{array}$ & $\begin{array}{c}0.010 \\
(0.016)\end{array}$ & $\begin{array}{c}0.008 \\
(0.013)\end{array}$ & $\begin{array}{c}-0.011^{\star \star \star} \\
(0.002)\end{array}$ & $\begin{array}{l}-0.001 \\
(0.002)\end{array}$ & $\begin{array}{c}-0.006^{\star \star \star} \\
(0.001)\end{array}$ \\
\hline Circulation & & $\begin{array}{l}-0.010 \\
(0.013)\end{array}$ & $\begin{array}{l}-0.005 \\
(0.012)\end{array}$ & $\begin{array}{c}0.002 \\
(0.002)\end{array}$ & $\begin{array}{l}-0.004 \\
(0.003)\end{array}$ & \\
\hline $\begin{array}{l}\text { Editions per } \\
\text { week }\end{array}$ & $\begin{array}{l}-0.015 \\
(0.026)\end{array}$ & $\begin{array}{l}0.013 \\
(0.011)\end{array}$ & $\begin{array}{c}0.001 \\
(0.010)\end{array}$ & $\begin{array}{l}-0.001 \\
(0.002)\end{array}$ & & $\begin{array}{l}-0.002 \\
(0.002)\end{array}$ \\
\hline $\begin{array}{l}\text { Press support* } \\
\text { Circulation }\end{array}$ & & $\begin{array}{c}0.010 \\
(0.012)\end{array}$ & & $\begin{array}{c}-0.010^{\star \star \star} \\
(0.002)\end{array}$ & $\begin{array}{c}0.021^{\star \star \star} \\
(0.003)\end{array}$ & \\
\hline $\begin{array}{l}\text { Press support* } \\
\text { Editions per } \\
\text { week }\end{array}$ & $\begin{array}{c}0.066 \\
(0.046)\end{array}$ & & $\begin{array}{l}0.048^{\star *} \\
(0.023)\end{array}$ & & & $\begin{array}{l}0.008 \\
(0.006)\end{array}$ \\
\hline Scrape hour & $\begin{array}{l}0.084^{*} \\
(0.045)\end{array}$ & $\begin{array}{l}0.026^{\star} \\
(0.013)\end{array}$ & $\begin{array}{c}0.019 \\
(0.015)\end{array}$ & $\begin{array}{l}0.006^{\star \star} \\
(0.003)\end{array}$ & & \\
\hline Scrape hour $\wedge^{\wedge}$ & $\begin{array}{l}-0.003 \\
(0.002)\end{array}$ & $\begin{array}{l}-0.001^{*} \\
(0.001)\end{array}$ & $\begin{array}{l}-0.001 \\
(0.001)\end{array}$ & $\begin{array}{l}-0.000^{\star} \\
(0.000)\end{array}$ & & \\
\hline $\begin{array}{l}\text { Unemployment } \\
\text { growth }\end{array}$ & & $\begin{array}{l}-0.142 \\
(0.428)\end{array}$ & $\begin{array}{l}-0.099 \\
(0.413)\end{array}$ & & $\begin{array}{l}0.016 \\
(0.154)\end{array}$ & $\begin{array}{l}0.004 \\
(0.152)\end{array}$ \\
\hline Population & $\begin{array}{c}0.000^{\star \star \star} \\
(0.000)\end{array}$ & $\begin{array}{c}0.000^{\star \star \star} \\
(0.000)\end{array}$ & $\begin{array}{c}0.000^{\star \star \star} \\
(0.000)\end{array}$ & $\begin{array}{c}0.000^{\star \star \star} \\
(0.000)\end{array}$ & $\begin{array}{c}0.000^{\star \star \star} \\
(0.000)\end{array}$ & $\begin{array}{c}0.000^{\star \star \star} \\
(0.000)\end{array}$ \\
\hline Latitude & $\begin{array}{l}0.005 \\
(0.004)\end{array}$ & $\begin{array}{l}0.003^{\star \star} \\
(0.001)\end{array}$ & $\begin{array}{l}0.003^{\star} \\
(0.001)\end{array}$ & & $\begin{array}{l}-0.000 \\
(0.000)\end{array}$ & $\begin{array}{l}-0.000 \\
(0.000)\end{array}$ \\
\hline Longitude & $\begin{array}{c}0.011^{\star \star \star} \\
(0.004)\end{array}$ & $\begin{array}{l}0.001 \\
(0.001)\end{array}$ & $\begin{array}{c}0.001 \\
(0.001)\end{array}$ & $\begin{array}{c}0.000^{\star \star \star} \\
(0.000)\end{array}$ & $\begin{array}{c}0.001^{\star \star \star} \\
(0.000)\end{array}$ & $\begin{array}{c}0.001^{\star \star \star} \\
(0.000)\end{array}$ \\
\hline _cons & $\begin{array}{c}-0.680^{* *} \\
(0.335)\end{array}$ & $\begin{array}{c}-0.308^{\star \star \star} \\
(0.113)\end{array}$ & $\begin{array}{l}-0.239^{\star} \\
(0.124)\end{array}$ & $\begin{array}{l}-0.027^{\star} \\
(0.014)\end{array}$ & $\begin{array}{l}0.016 \\
(0.022)\end{array}$ & $\begin{array}{c}0.024 \\
(0.023)\end{array}$ \\
\hline$r^{2}$ & 0.403 & 0.417 & 0.446 & 0.176 & 0.387 & 0.351 \\
\hline $\mathrm{N}$ & 156 & 156 & 156 & 156 & 156 & 156 \\
\hline
\end{tabular}

${ }^{\star} p<0.1,{ }^{\star \star} p<0.05,{ }^{* \star *} p<0.01$ 
Table A7. Robustness test with fractional regression

\begin{tabular}{|c|c|c|c|c|c|c|}
\hline \multirow[b]{2}{*}{ Press support } & \multirow{2}{*}{$\begin{array}{c}\text { Hard news } \\
-0.091 \\
(0.112)\end{array}$} & \multicolumn{2}{|c|}{ Politics } & \multirow{2}{*}{$\begin{array}{c}\begin{array}{c}\text { Local } \\
\text { politics }\end{array} \\
0.156 \\
(0.212)\end{array}$} & \multicolumn{2}{|c|}{ Area politics } \\
\hline & & $\begin{array}{l}-0.136 \\
(0.187)\end{array}$ & $\begin{array}{l}-0.293 \\
(0.187)\end{array}$ & & $\begin{array}{c}-0.352^{\star \star \star} \\
(0.098)\end{array}$ & $\begin{array}{c}-0.332^{\star \star \star} \\
(0.117)\end{array}$ \\
\hline Independent & & $\begin{array}{c}0.097 \\
(0.196)\end{array}$ & $\begin{array}{c}0.083 \\
(0.176)\end{array}$ & $\begin{array}{c}-1.569^{\star \star *} \\
(0.336)\end{array}$ & & \\
\hline State owned (NRK) & $\begin{array}{c}0.078 \\
(0.101)\end{array}$ & $\begin{array}{c}0.144 \\
(0.276)\end{array}$ & $\begin{array}{c}0.036 \\
(0.226)\end{array}$ & $\begin{array}{c}-1.162^{\star \star \star} \\
(0.157)\end{array}$ & $\begin{array}{l}-0.037 \\
(0.129)\end{array}$ & $\begin{array}{c}-0.313^{\star \star \star} \\
(0.076)\end{array}$ \\
\hline Editions per week & & $\begin{array}{l}-0.170 \\
(0.238)\end{array}$ & $\begin{array}{l}-0.086 \\
(0.210)\end{array}$ & $\begin{array}{l}0.193 \\
(0.257)\end{array}$ & $\begin{array}{l}-0.267 \\
(0.172)\end{array}$ & \\
\hline Circulation & $\begin{array}{l}-0.063 \\
(0.110)\end{array}$ & $\begin{array}{c}0.229 \\
(0.167)\end{array}$ & $\begin{array}{c}0.017 \\
(0.182)\end{array}$ & $\begin{array}{l}-0.031 \\
(0.173)\end{array}$ & & $\begin{array}{l}-0.127 \\
(0.141) \\
\end{array}$ \\
\hline $\begin{array}{l}\text { Press support } \\
\text { Circulation }\end{array}$ & & $\begin{array}{c}0.230 \\
(0.255)\end{array}$ & & $\begin{array}{c}-1.216^{\star \star \star} \\
(0.249)\end{array}$ & $\begin{array}{c}0.939^{\star * \star} \\
(0.173)\end{array}$ & \\
\hline $\begin{array}{l}\text { Press support* } \\
\text { Editions per week }\end{array}$ & $\begin{array}{c}0.267 \\
(0.187)\end{array}$ & & $\begin{array}{l}0.598^{\star *} \\
(0.283)\end{array}$ & & & $\begin{array}{l}0.491^{*} \\
(0.288)\end{array}$ \\
\hline Scrape hour & $\begin{array}{l}0.408^{*} \\
(0.217)\end{array}$ & $\begin{array}{l}0.562 \\
(0.409)\end{array}$ & $\begin{array}{c}0.403 \\
(0.427)\end{array}$ & $\begin{array}{l}0.681^{\star \star} \\
(0.316)\end{array}$ & & \\
\hline Scrape hour^2 & $\begin{array}{l}-0.014 \\
(0.009)\end{array}$ & $\begin{array}{l}-0.023 \\
(0.017)\end{array}$ & $\begin{array}{l}-0.016 \\
(0.018)\end{array}$ & $\begin{array}{l}-0.028^{\star \star} \\
(0.014)\end{array}$ & & \\
\hline $\begin{array}{l}\text { Unemployment } \\
\text { growth }\end{array}$ & & $\begin{array}{c}-4.356 \\
(10.703)\end{array}$ & $\begin{array}{c}-2.547 \\
(10.608)\end{array}$ & & $\begin{array}{l}-11.396 \\
(11.963)\end{array}$ & $\begin{array}{l}-12.128 \\
(12.028)\end{array}$ \\
\hline Population & $\begin{array}{l}0.000^{\star \star \star} \\
(0.000)\end{array}$ & $\begin{array}{l}0.000^{\star \star \star} \\
(0.000)\end{array}$ & $\begin{array}{c}0.000^{\star \star \star} \\
(0.000)\end{array}$ & $\begin{array}{l}0.000^{\star \star *} \\
(0.000)\end{array}$ & $\begin{array}{c}0.000^{\star \star \star} \\
(0.000)\end{array}$ & $\begin{array}{c}0.000^{\star \star *} \\
(0.000)\end{array}$ \\
\hline Latitude & $\begin{array}{c}0.022 \\
(0.017)\end{array}$ & $\begin{array}{l}0.072^{\star \star} \\
(0.028)\end{array}$ & $\begin{array}{l}0.066^{\star \star} \\
(0.030)\end{array}$ & & $\begin{array}{l}-0.022 \\
(0.030)\end{array}$ & $\begin{array}{l}-0.032 \\
(0.032)\end{array}$ \\
\hline Longitude & $\begin{array}{c}0.049^{\star \star \star} \\
(0.016)\end{array}$ & $\begin{array}{l}0.014 \\
(0.022)\end{array}$ & $\begin{array}{c}0.016 \\
(0.022)\end{array}$ & $\begin{array}{c}0.051^{\star \star *} \\
(0.015)\end{array}$ & $\begin{array}{c}0.087^{\star \star *} \\
(0.018)\end{array}$ & $\begin{array}{c}0.092^{\star \star \star} \\
(0.018)\end{array}$ \\
\hline _cons & $\begin{array}{c}-5.308^{\star \star \star} \\
(1.567)\end{array}$ & $\begin{array}{c}-11.226^{\star \star \star} \\
(2.756)\end{array}$ & $\begin{array}{l}-9.849^{\star \star \star} \\
(2.997)\end{array}$ & $\begin{array}{c}-9.208^{\star \star \star} \\
(1.733)\end{array}$ & $\begin{array}{l}-3.873^{\star \star} \\
(1.734)\end{array}$ & $\begin{array}{l}-3.295^{*} \\
(1.803)\end{array}$ \\
\hline $\mathrm{N}$ & 156 & 156 & 156 & 156 & 156 & 156 \\
\hline
\end{tabular}

${ }^{*} p<0.1,{ }^{* *} p<0.05,{ }^{* \star *} p<0.01$

\section{References appendix}

Elgesem, D., Feinerer, I. \& Steskal, L. (2016). Bloggers' responses to the Snowden affair: Combining automated and manual methods in the analysis of news blogging. Computer Supported Cooperative Work (CSCW), 2(25): 167-191.

Fiva, J., Halse, A. \& Natvik, G. J. (2012). Local government dataset. Dataset available at esop.uio.no.

Lehman-Wilzig, S. N. \& Seletzky, M. (2010). Hard news, soft news, 'general' news: The necessity and utility of an intermediate classification. Journalism, 11(1): 37-56.

Rabe-Hesketh, S. \& Skrondal, A. (2008). Multilevel and longitudinal modeling using Stata. STATA press.

Reinemann, C., Stanyer, J., Scherr, S. \& Legnante, G. (2012). Hard and soft news: A review of concepts, operationalizations and key findings. Journalism, 13(2): 221-239.

Wooldridge, J. M. (2010). Econometric analysis of cross section and panel data. Cambridge: MIT press.

Copyright: (C) 2019 The Author(s) and Nordicom. This is an open-access article distributed under the terms of the Creative Commons Attribution 4.0 International License (CC BY-NC-ND 4.0). 